\title{
Teaching challenges on the use of storytelling in elementary science lessons
}

\author{
Hajah Nuruljannah Haji Matamit, Roslinawati Roslan, Masitah Shahrill, Hardimah Mohd Said \\ Sultan Hassanal Bolkiah Institute of Education, Universiti Brunei Darussalam, Brunei Darussalam
}

\begin{tabular}{|c|c|}
\hline Article Info & ABSTRACT \\
\hline Article history: & This study investigated the use of storytelling in teaching elementary science \\
\hline Received Mar 20, 2020 & on the topic of 'Sense Organs' at the Grade 1 level. A total of 21 students \\
\hline Revised June 29, 2020 & the study. The qualitative analyses of the observations and video recordings \\
\hline Accepted Jul 18, 2020 & $\begin{array}{l}\text { resulted in the classifications of the challenges faced when storytelling } \\
\text { was used in the lessons. The four identified categories were the language }\end{array}$ \\
\hline Keywords: & $\begin{array}{l}\text { aspect, development aspect, external challenges and existing knowledge. } \\
\text { These categories were then used to investigate further any aspect that }\end{array}$ \\
\hline Challenges & would develop the challenges into the teaching and learning of science \\
\hline Classifying & ig storytelling. Despite identifying the challenges in using storytelling \\
\hline Elementary science & science concepts. \\
\hline Science concepts & \\
\hline
\end{tabular}

This is an open access article under the CC BY-SA license.

Storytelling

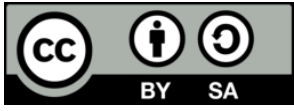

\section{Corresponding Author:}

Masitah Shahrill,

Sultan Hassanal Bolkiah Institute of Education,

Universiti Brunei Darussalam,

Jalan Tungku Link, Gadong, BE 1410, Bandar Seri Begawan, Brunei Darussalam.

Email: masitah.shahrill@ubd.edu.bn

\section{INTRODUCTION}

Everyone has the basic repertoire of telling stories every day without realizing that an individual is getting information of a certain topic. Through stories, one may develop certain skills that symbolize imagination, emotion and truth found in the universe [1]. The goal of storytelling is usually for immediate organization of information, which provides continuous engagement, enjoyment and commitment of each representative [2-4]. In the early years of education, children are expected to acquire learning activities that trigger their imaginative self especially when these children were born with different cultural background. The children should be trained with a lot of opportunities in new literacy such as digital storytelling at earlier stages [5-7].

In brief, information is naturally organized by using narrative, but storytelling is used as an immediate means that the narrative represents $[2,8]$. This relates back to the word imagination, which leads storytelling as an influential tool that provides numerous benefits for students [9-11]. Researchers had found remarkable results of what storytelling has done as a good teaching approach especially in literacy skills. At most, storytelling is broadly looked at in language classes. However, studies are still lacking in adapting the use of storytelling in science education. Many of the teachers' concerns relate to students not understanding science concept, and its application to life. This rings true in Brunei Darussalam where science subject is considered to be one of the challenging subjects to learn as the subject is taught in the English language. Students in Brunei face double challenges of learning science, as they have to learn the language of science itself as well as the English language. To help students learn science, there is a possibility of using storytelling to help students engage in science, as stories are easily acceptable by young children. 
Furthermore, storytelling in primary schools are proposed to help improve students' linguistic and literacy skills, promote their interaction, synthesis and analysis [12]. In so doing, it adds to the limited literature on using storytelling to teach science particularly at the elementary level. Many of the studies conducted on storytelling in science also tend to explore the benefits and effects of storytelling in teaching certain science concepts. This study is one of few studies, which discussed the challenges of using this approach in young children through action research.

Storytelling was initiated many years before the formal education started [13, 14]. Storytelling accompanied with simple chants, in big ceremony by the early men and grew to be rituals [9]. Stories have been heard and passed down to generations meaningfully were presented with oral expression [15, 16]. Storytelling is a traditional Gurukala and Harikhata teaching methods before the Western introduced the formal education $[17,18]$. In fact, it was the beginning of all before stories changed into pictures, written words, and books. Thus, its definition is subjective, and there is no formal form to explain it. Storytelling is also defined as recounting a tale of an audience through voice and gesture [19]. It definitely means that there is no involvement of script of story in hand while delivering it. As much as storytelling is mostly known to apply for the literacy ability in language classes, it is indeed, that storytelling expands knowledge in other subject areas such as Science. This helps in simplifying complex keywords, or explaining a complex concept into simpler and easier ways to understand [18, 20, 21].

\section{RESEARCH METHOD}

This aim of this study is to investigate the challenges faced on using storytelling in improving students' understanding of the science topic 'Sense Organs'. The purpose was to provide reflective analysis on improving the use of storytelling when it is used to young children. The research question pose for this study is "What are the challenges of teaching the topic 'Sense Organs' uses storytelling at the elementary science classroom?" Teaching Sense Organs is important at a young age as it reveals that the senses function differently. It is essential to make students differentiate these senses as it is and also fundamental to let students analyze the aspects of them working together in everyday life.

The participants of this study consisted of 21 Grade 1 students, with age ranging from 6 to 7 years old, enrolled in a government elementary school in one of the districts in Brunei. Although the medium of instruction of science subjects in Brunei is in the English language, the Malay language was also used simultaneously for their better understanding and expected engagement in class participation. The students were of mixed abilities. The participants practiced learning with storytelling for the topic 'Sense Organs' in two learning environments, the classroom and the science laboratory. Additionally, they have learnt the topic on body parts prior to this study. Briefly given in Table 1 are the details of the three lessons, which were conducted by the teacher (the first author) with the use of storytelling. All the lessons were video-recorded.

Table 1. Details of the lessons conducted with storytelling

\begin{tabular}{|c|c|c|}
\hline Lessons & Lesson Content & Titles of the Story \\
\hline $\begin{array}{l}\text { Lesson 1: What are your sense } \\
\text { organs? }\end{array}$ & $\begin{array}{l}\text { Identifying the 'Sense Organs' (eyes, nose, ears, skin and tongue) } \\
\text { and recall the spelling }\end{array}$ & $\begin{array}{l}\text { The Mystery of the Boy } \\
\text { with No Sense Organs }\end{array}$ \\
\hline $\begin{array}{l}\text { Lesson 2: How important is your } \\
\text { sense organs (The function)? }\end{array}$ & $\begin{array}{l}\text { Differentiate the uses of the five senses, identify the importance } \\
\text { of the five senses and apply the idea of senses to any task }\end{array}$ & The Best Sense Organs \\
\hline $\begin{array}{l}\text { Lesson 3: How do you use your } \\
\text { sense organs? }\end{array}$ & Application of the sense organs in everyday doings & $\begin{array}{l}\text { Goldilocks \& the Three } \\
\text { Bears }\end{array}$ \\
\hline
\end{tabular}

Upon completing the lessons, the video recordings were reviewed and observations were noted into the field notes. An observation analysis form was used for each lesson. The descriptive coding process by Saldaña [22] was used in analyzing the challenges on the use of storytelling. The data obtained were then analyzed by determining keywords, phrases, actions and students' reactions that were seen as obvious from the video recordings. Subsequently, categories emerged from analyzing the challenges on the use of storytelling in the classrooms. The categories and codes were then compared with the other researchers to establish inter-coder reliability. The researchers of this study agreed to find the common categories and codes analyzed from the video recordings. Importantly, all ethical procedures such as the relevant permission and consents from the school, parents or guardians and students were sought prior to conducting the study.

\section{RESULTS AND DISCUSSION}

The qualitative data analysis resulted from coding of the video recordings of the three lessons. The codes were then categorized into four main categories: 1) the language aspect, 2) the development

Teaching challenges on the use of storytelling in elementary science ... (Hajah Nuruljannah Haji Matamit) 
aspect, 3) the external challenges, and 4) the existing knowledge. These categories were used to help investigate any aspect that would develop the challenges into the teaching and learning of science using storytelling. The summary of the categories and their codes that falls in each category is given in Table 2.

Table 2. The four categories in challenges of using storytelling in the science classroom

\begin{tabular}{ll}
\multicolumn{1}{c}{ Codes } & \multicolumn{1}{c}{ Category } \\
\hline Language; Questions; Responses & The language aspect \\
Teaching aids; Activity; Misinterpretation of information & Development aspect \\
Environment; Behavior & External challenges \\
Expectation; Background knowledge & The existing knowledge \\
\hline
\end{tabular}

\subsection{The identified codes}

Language - Language was seen as a barrier in the lessons and it was one of the main problems faced by the teacher to express within the story, and while delivering normal instruction. Most times, code switching from English to Malay languages, and translations of a whole sentence were used interchangeably during the storytelling. It was obvious from the recordings that the teacher uses them frequently, extending the storytelling sessions from nine to twenty minutes. Examples of typical occurrences on teacher's code switch and translation during storytelling can be found in Table 3.

Table 3. Code switching and translation of a part of a story during the intervention

\begin{tabular}{cl}
\hline $\begin{array}{c}\text { Ways of } \\
\text { Delivering }\end{array}$ & \multicolumn{1}{c}{ Teacher's Speech } \\
\hline $\begin{array}{c}\text { Translation } \\
\text { Code switch }\end{array}$ & $\begin{array}{l}\text { (Let's take a walk outside) } \\
\text { At the same time, Goldilocks was actually jalan-jalan dalam hutan (strolling in the forest) }\end{array}$ \\
\hline
\end{tabular}

Question - From the recordings, question and answer sessions were observed nonetheless like any other classes. Questions were asked consistently even during the storytelling session. In addition, the questions were sometimes asked to elicit students' point of view. Throughout the recordings, most of the questions asked to the students were focused on the knowledge level that is to define, to identify, to name, and to match. For example, 'Where's your tongue?' and 'What's greedy?' Other questions included some close-ended questions requiring students to answer yes or no. The questions did not challenge students' thinking abilities despite the usefulness in using storytelling.

Responses - In finding the challenges of using storytelling during the lessons, responses from students were seen as a factor to see whether students were able to comprehend the stories told, or otherwise. When questioning the students, the higher ability students mainly do the answering. In other situations, the students gave choral answers with the reassurance of the teacher's question such as, Teacher: "Setuju kah inda?" (Do you agree or not?); Students: "Setuju..." (Agree). Sometimes the students uttered their responses without thinking thoroughly, and sometimes responded with one-word responses, leaving the high order questions unanswered, such as the teacher asking, "Why can't we choose only one sense organ as the most important one?"

Misinterpretation of information - In relation to the knowledge development, the students considered learning basic information about parts of senses, but it eventually took time to have the information retained in their minds. Two of the senses were always wrongly interpreted due to the language used when being asked, such as shown in the Table 4, which were asked using the Malay language. Shown in both examples, touch and hold were different semantically. However, in the Malay language, it could mean the same thing as to taste the food, especially when spoken in Bruneian Malay; rasa (taste) would also mean to eat and to touch an item. The students interpreted them by using body parts because skin touches items, and so does the hands. While tongue is part of the mouth, the students interpreted the mouth as being able to taste the food, instead of the tongue.

Teaching aids - During the course of the lessons, three teaching aids were used in conveying the stories. On the first day, the glove puppet (shown in Figure 1) and PowerPoint presentation of scenes were incorporated in the story, secondly, laminated pictures of sense organs (Figure 2). 
Table 4. Misinterpretation of information during discussion after storytelling

\begin{tabular}{cc}
\hline Teacher's Speech & Students' Response \\
\hline Pakai apa kamu rasa ani? (What do you use to touch this?) & Tangan (Hands) \\
Pakai apa kamu pigang ani? (What do you use to hold this?) & Mulut (Mouth) \\
\hline
\end{tabular}

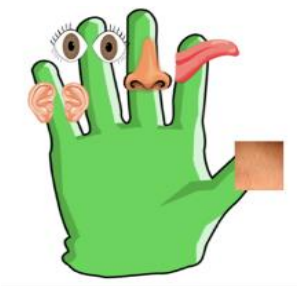

Figure 1. Story glove for day 1

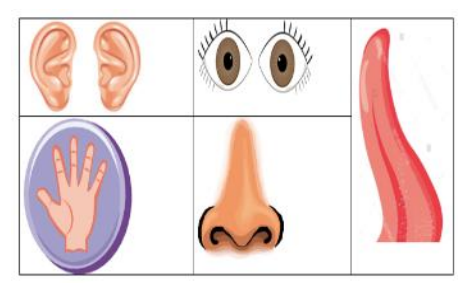

Figure 2. Laminated pictures for storytelling day 2

Thirdly, using models of house items for Goldilocks and the three bears (see Figure 3) and PowerPoint presentation of scenes were used in the storytelling. It was observed that during the first day, the most challenging task was that the students were distracted. They were seen uninterested during the first part of the story, some students talked to each other, and two male students were fighting. This was mainly due to the students dividing their focus on three things - the story, the glove and the pictures shown. The teacher then put away the puppet, and delivered the lesson normally by referring to the PowerPoint presentation only. However, as it came towards the end of the instruction and before the next activity, the teacher took out the puppet for the students to give farewell, one student complained by saying "Lagi kah cikgu, balik-balik jua" (This puppet again?)', with a disappointed tone.

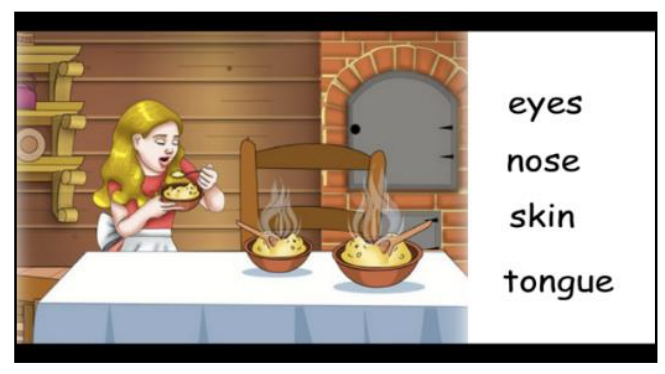

Figure 3. Goldilocks eating porridge in the bears' kitchen

In comparison, the second day of the storytelling session was the calmest of all the three lessons. This was seen from the recordings where the teacher used laminated pictures of sense organs as a teaching aid. The students were told to sit on the floor, and they were silent and seen focused while the storytelling was on going. The third day of storytelling had similar teaching aids with the first day. However, the students were more engaged into the story. They were focusing on the models and the story at the same time, as the teacher gradually used the PowerPoint presentation towards the end of the story as the conclusion. This showed that students were able to follow the flow of story with less distraction. Interestingly, as the story used models made for students to feel and tell the texture of the materials, they were very excited, and little fights between them occurred, as they all wanted to touch the model.

Activity - In preparation of the lessons, the teacher included activities preceding the storytelling. There were hands on activities of matching the sense organs in a group, simple experimentation of using sense organs and discussions about the story in relation to the use of sense organs. Unfortunately, the matching of sense organs group activity was excluded from lesson one because of the limitation of time. In lesson 2, the teacher seemed to take control of the activity without stimulating the students' thinking into deeper thoughts of the experiment.

Environment - For the Science subject, the students get to study in the science laboratory. Hence during the lessons, the students spent two days in the science lab, and one in the classroom. Another observation that is included in the challenges of conducting a lesson using storytelling is the gathering

Teaching challenges on the use of storytelling in elementary science ... (Hajah Nuruljannah Haji Matamit) 
of students in one area to convey the story. The science laboratory, despite the ease of access for the interactive whiteboard for the PowerPoint presentation, the sitting area was smaller. As the students were sitting down, the area was packed and they were easily distracted by the noises made by their friends. This can be related to the lesson on day three where students fought and competed with each other in order to look at the models presented at the front of the class. This made some students complaining by saying "Inda nampak cikgu!"' (I cannot see teacher!).

Behavior - The observations from the video were pertinent as it depicts the students' reactions towards the use of storytelling. For example, in the first lesson some students distracted themselves by talking with each other, and some were even yawning. In the second lesson, two students leaned their heads on the table throughout the storytelling. While the on the third day, some of the students were fighting over on who to volunteer in holding the model for storytelling. All of these incidents made the teacher pause telling the story to gain back their attention. Unfortunately, this had caused students to forget the story easily, especially when the teacher asked them at which part of the story was paused.

Expectation - This was seen in most of the teacher's parts of the lessons especially when questions were asked to the students. The teacher had expected the students to be able to understand the story thus able to answer the questions with no guidance. Afterwards, as the students were found incapable of answering the questions, the teacher gave up and told them the answers straight away. Other times, the teacher gave students obvious clues, so that the students were able to answer immediately.

Background knowledge - The students were taught 'Body Parts' before the topic on 'Senses', hence they had some background knowledge on the topic. With the confusion of the terms and the use of sense organs - tongue and skin, into mouth and hand respectively, this shows that the terms used in the storytelling had not been retained by the students successfully. Therefore, several repetitions of the basic names of senses were told at most times in order for students to correct themselves.

\subsection{The categories from the codes}

The Language Aspect - This category was formed from the three codes - language, questions and responses, as these three involved the languages used in the class. Among all, these three resulted the most challenges in terms of delivering the content of the stories as part of the science instruction.

The Development Aspect - This category falls into labeling the retention of information into students' learning, and that external factors to help develop students' understanding were needed and viewed by the coding selected for this category. The codes have described the lesson preparation and its quality of a lesson especially on what was being prepared, and how good students can gain through the included activities.

The External Challenges - This category contained the external analyses that were not obviously showed by sound or speech from the video recordings. Based on the analyses, the codes behavior and environment were found as features that showed the incompatibility of the area used for the students to gather for the story session, the students' facial reactions and actions while the story was on-going. The codes assisted the teacher to make any appropriate modifications in her lessons.

The Existing Knowledge - This category that formed from the codes expectation and background knowledge related to the teacher as the questioner and the students in answering the questions asked to them. Asking questions to the students served the positive purpose for their learning, but the video lacked of evidence that showed students were able to recall some information shared during the storytelling sessions. It also showed the teacher's expectations that the students were able to retain the new information after three days. However, the students tend to use their background knowledge of the topic taught before the lessons with the storytelling sessions.

\section{DISCUSSION}

The results of this study showed how science instructions in the elementary science classroom were delivered using storytelling that created a distinctive constructive learning. Using storytelling in science education can be said as more successful when teachers are devoted in providing quality teaching in terms of the time spent preparing the materials, teaching aids and activities for their students. However, regardless of all the preparations, all teaching strategies would thereby face challenges. One of the challenges is that it takes a long time to create a story with all the lack of related information, which can create hardship to their education [6, 23]. Previous studies have indicated that storytelling is seen as a powerful approach and resulted in positivity for students' teaching [3, 9, 10, 24-27]. The evidence of the challenges in teaching using storytelling in the classroom made learning science different than other methods. From this study, the four classifications formed in the qualitative findings identified how the challenges are commonly experienced in other styles of teaching as well [28-38]. 
Language barrier has continuously been the main problem when teaching the non-native speakers of the language. In the case of this study, the use of the Malay language has been widely applied to the Grade 1 students during their previous months of science learning, and the application of English language storytelling in the classroom was seen as difficult. Therefore, the code switching and translation were done purposely together at all times to let the students follow what is taught. With the repetition of the same sentences in two different languages, it took more time for the sessions to be completed, the climax of the story could become dull, and existence of instances where students could be easily distracted. In fact, it is obviously important to reflect stories that would interpret relationship, motives and feelings together [39, 40]. This study also found external factors that contribute to the challenges in delivering the stories. The environment plays an important factor for a comfortable teaching situation [41]. A great environment for conducting a lesson using storytelling is when students are gathered in one area comfortably, listening to the teacher [27].

Beyond these challenges, the class in this present study experienced something different with engagement relationship between the teacher and the students enhanced, evidenced especially from the observed video recordings in which the students were excited seeing the models used in the storytelling. The students also had the opportunity to learn science from the introduction of stories, and by storytelling, get to unwrap information through scaffolding. By introducing storytelling, it allows students to expand their imagination, and enriched their learning ability through understanding of complex science concept in simpler and fun explanations through the conveyed stories.

\section{CONCLUSION}

It is widely known that storytelling has positive effects to primary school students' learning by engaging them in the lessons, spark their creativity and improve their literacy and linguistic skills. However, teachers should be mindful in choosing the right story for their lessons and this requires careful planning and preparation. The challenges discussed earlier provided reflective insights on using storytelling in teaching science for non-native English language students. Students need to be taught the right vocabulary, using students' first language (L1) and code-switching at times to help students comprehend the stories conveyed. This research has its own limitations, as the findings of this qualitative study are not generalizable. This can be achieved by utilizing quantitative research to enhance the credibility of this study. Further research is needed in exploring the challenges of using storytelling in science and perhaps finding the possible solutions to overcome these challenges of using stories to young children in the future.

\section{REFERENCES}

[1] E. Grugeon and P. Garder, The art of storytelling for teachers and pupils: Using stories to develop literacy in primary classrooms, London: David Fulton, 2000.

[2] A. K. Daniel, Storytelling across the primary curriculum, Florence: Taylor and Francis, 2013.

[3] S. Aguilar Cubillo and J. Alcántara Manzanares, "Storytelling as a tool for science teaching in bilingual primary education," X Congreso Internacional Sobre Investigación En Didáctica De Las Ciencias (10 ${ }^{\text {th }}$ International Congress on Research in Didactical Science), pp. 5085-5090, 2017.

[4] M. Pulimeno, P. Piscitelli and S. Colazzo, "Children's literature to promote students' global development and wellbeing," Health Promotion Perspectives, vol. 10, no. 1, pp. 13-23, 2020.

[5] A. Yamaç and M. Ulusoy, "The effect of digital storytelling in improving the third graders' writing skills," International Electronic Journal of Elementary Education, vol. 9, no. 1, pp. 59-86, 2017.

[6] M. M. Cheng and H. H. Chuang, "Learning processes for digital storytelling scientific imagination," EURASIA Journal of Mathematics, Science and Technology Education, vol. 15, no. 2, pp. 1-17, 2019.

[7] J. Wu and D. T. V. Chen, "A systematic review of educational digital storytelling," Computers \& Education, vol. 147, no. 1, pp. 1-16, 2020.

[8] V. J. C. Arevalo, et al, "Storylines for practice: A visual storytelling approach to strengthen the science-practice interface," Sustainability Science, vol. 15, no. 4, pp. 1-20, 2020.

[9] P. Cooper, R. Collins and M. Saxby, "The power of story," Melbourne: Macmillan Education Australia, 1992.

[10] S. Y1lmaz, Z. Temiz, Z. and G. Karaarslan Semiz, "Children's understanding of human-nature interaction after a folk storytelling session," Applied Environmental Education \& Communication, vol. 19, no. 1, pp. 88-100, 2020.

[11] J. Koch, "Science stories: Science methods for elementary and middle school teachers (5th ed.)," Australia: Wadsworth Cengage Learning, 2013.

[12] C-M. Hung, G.-J. Hwang and I. Huang, "A project-based digital storytelling approach for improving students' learning motivation, problem-solving competence and learning achievement," Journal of Educational Technology \& Society, vol. 15, no. 4, pp. 368-379, 2012.

[13] J. A. Rose, "To teach science, tell stories," Master dissertation, North Carolina: Graduate School of Duke University, 2017. 
[14] B. Anilan, "Views and experiences of pre-service teachers on the use of stories in teaching science." Journal of Baltic Science Education, vol. 17, no. 4, pp. 605-619, 2018.

[15] N. S. Al-Mansour and R. E. A. Al-Shorman, "The effect of teacher's storytelling aloud on the reading comprehension of Saudi elementary stage students," Journal of King Saud University-Languages and Translation, vol. 23, no. 2, pp. 69-76, 2011.

[16] I. Satriani, "Storytelling in teaching literacy: Benefits and challenges," English Review: Journal of English Education, vol. 8, no. 1, pp. 113-120, 2019.

[17] N. Mercer, The guided construction of knowledge: Talk amongst teachers and learners, Clevedon, UK: Multilingual Matters, 1995.

[18] R. Roslan, "The use of stories and storytelling in primary science teaching and learning," Studies in Education, vol. 12, no. 1, pp. 79-89, 2008.

[19] National Council of Teachers of English, Teaching Storytelling: A Position Statement from the Committee on Storytelling, Urbana: National Council of Teachers of English, 2000.

[20] R. Roslan, M. Panjang, N. Yusof and M. Shahrill, "Teacher's feedback in teaching Bruneian primary science classroom," On the Horizon, vol. 26, no. 2, pp. 122-136, 2018.

[21] I. Y. Maureen, H. van der Meij and T. de Jong, "Enhancing storytelling activities to support early (digital) literacy development in early childhood education," International Journal of Early Childhood, vol. 52, no. 1, pp. 1-22, 2020.

[22] J. Saldaña, The coding manual for qualitative researchers, Thousand Oaks, CA: Sage, 2015.

[23] Y. Kurniawan and R. Muliyani, "A development design of digital story conceptual change-oriented in physics subject," JIPF (Jurnal Ilmu Pendidikan Fisika), vol. 4, no. 2, pp. 110-117, 2019.

[24] J. Bruner, "Life as a narrative", in A. Dyson and C. Genishi (Eds.), "The need for story: Cultural diversity in classroom and community," Urbana, IL: National Council for Teachers of English, pp. 28-37, 1994.

[25] N. J. Reeder, "A qualitative case study of natural storytelling strategies used at the Nantahala school," Electronic Theses and Dissertation, East Tennessee State University, 2009.

[26] P. Kokkotas, A. Rizaki and K. Malamitsa, "Storytelling as a strategy for understanding concepts of electricity and electromagnetism," Interchange, vol. 41, no. 4, pp. 379-405, 2010.

[27] R. Hibbin, "Oral storytelling, speaking and listening and the hegemony of literacy: Non-instrumental language use and transactional talk in the primary classroom," Changing English, vol. 23, no.1, pp. 52-64, 2016.

[28] M. Shahrill, S. Mahalle, R. Matzin, M. H. S. Hamid and L. Mundia, "A comparison of learning styles and study strategies used by low and high math achieving Brunei secondary school students: Implications for teaching," International Education Studies, vol. 6, no. 10, pp. 39-46, 2013.

[29] M. Shahrill, R. C. I. Prahmana and R. Roslan, "The relationships within the mathematical content of teachers' lesson sequences," Journal of Physics: Conference Series, vol. 943, no. 1, pp. 1-9, 2018.

[30] Z. Suhaimi, M. Shahrill and K. A. Tengah, "Incorporating the use of writing-to-learn strategy in grade 10 mathematics lessons: The students' perspectives," Journal of Mathematics Education at Teachers College, vol. 7, no. 2, pp. 11-20, 2016.

[31] Z. Suhaimi, et al, "Exploring the use of journal writing in mathematics classroom," International Journal on Emerging Mathematics Education, vol. 1, no. 1, pp. 41-52, 2017.

[32] M. Huda, K. A Jasmi, A. Hehsan, M. I. Mustari, M. Shahrill, B. Basiron and S. K. Gassama, "Empowering children with adaptive technology skills: Careful engagement in the digital information age," International Electronic Journal of Elementary Education, vol. 9, no. 3, pp. 693-708, 2017.

[33] M. Huda, et al, "Empowering learning culture as student identity construction in higher education," In Shahriar, A., \& Syed, G. (Ed.), Student Culture and Identity in Higher Education. IGI Global, pp. 160-179, 2017.

[34] Masniladevi, R. C. I. Prahmana, Y. Helsa and M. Dalais, "Teachers' ability in using math learning media." Journal of Physics: Conference Series, vol. 943, no. 1, pp. 1-5, 2018.

[35] N. L. A. Halim, H. C. Li, M. Shahrill and R. C. I Prahmana, "Teaching strategies in the learning of highest common factor and lowest common multiple," Journal of Physics: Conference Series, vol. 943, no. 1, pp. 1-9, 2018.

[36] J. Mumu, R. C. I. Prahmana and B. Tanujaya, "Construction and reconstruction concept in mathematics instruction," Journal of Physics: Conference Series, vol. 943, no. 1, pp. 1-7, 2018.

[37] D. Muhtadi, W. Sanusi, B. G. Kartasasmita and R. C. I. Prahmana, "The integration of technology in teaching mathematics," Journal of Physics: Conference Series, vol. 943, no. 1, pp. 1-8, 2018.

[38] A. P. Nurjanah and G. Anggraini, "Storytelling method to improve speaking skills in children aged 5-6 years (in Bahasa)," Jurnal Ilmiah Potensia, vol. 5, no. 1, pp. 1-7, 2020.

[39] J. Woodhouse, "Storytelling and narratives: Sitting comfortably with learning," in J. Woodhouse (Ed.), "Strategies for Health Care Education: How to teach in 21 ${ }^{\text {st }}$ Century," United Kingdom: Radcliffe Publishing Ltd, pp. 61-68, 2007.

[40] R. K. Panthi, B. C. Luitel and S. Belbase, "Strategies for promoting social justice in the math classroom," International Journal on Emerging Mathematics Education, vol. 2, no. 1, pp. 17-38, 2018.

[41] M. Shahrill and D. J. Clarke, "Pedagogical features that influence mathematics classroom practices-A Bruneian perspective,” Kasetsart Journal of Social Sciences, vol. 40, no. 2, pp. 341-348, 2019. 